\begin{tabular}{ccc}
\hline International Journal of Engineering \& Technology, $7(4.15)(2018) 427-430$ \\
SPC & Website: www.sciencepubco.com/index.php/IJET \\
Research paper & Technology \\
\hline
\end{tabular}

\title{
Granting of Organic Fertilizer and NPK Fertilizer to Growth and Results of Sweet Corn (Zea Mays. L)
}

\author{
Sri Hidayati ${ }^{1}$, Mahrus Ali $^{2 *}$, Sri Purwanti ${ }^{3}$, Nurul Huda ${ }^{4}$, Nurlina ${ }^{5}$ \\ ${ }^{1}$ Faculty of Agriculture Merdeka University Surabaya \\ ${ }^{2}$ Faculty of Agriculture Merdeka University Surabaya \\ ${ }^{3}$ Faculty of Agriculture Merdeka University Surabaya \\ *Corresponding author E-mail:sengkomahrus@gmail.com
}

\begin{abstract}
The aim of research is to test the combination of organic fertilizer and NPK fertilizer, test organic fertilizer, test NPK fertilizer that is suitable for the growth and yield of sweet corn. This research method using Randomized Block Design (RAK) arranged factorial consists of two factors, namely Organic Fertilizer (cage) with 3 levels of treatment (K) and NPK Fertilizer with 3 levels of treatment (M). Each treatment was repeated 3 times and each treatment combination consisted of two sample plants. The results of this study showed that the overall treatment of the combination of organic fertilizer and NPK fertilizer on the growth and yield of sweet corn plants did not show a real effect. Separately the treatment of organic fertilizer gave a very real effect on all observation variables, the average organic fertilizer as much as 17.5 tons / ha or $1.5 \mathrm{~kg} / \tan (\mathrm{K} 3)$ gave the highest growth and yield of sweet corn compared to other treatment, Separately the treatment of NPK fertilizer gave a very real influence on all observation variables, the average NPK fertilizer with a composition of $450 \mathrm{~kg} \mathrm{Urea}+150 \mathrm{~kg} \mathrm{TSP}+75 \mathrm{~kg} \mathrm{KCl}) / \mathrm{Ha}$ or $9 \mathrm{~g}+3 \mathrm{~g}+1.5 \mathrm{~g} / \mathrm{tan}(\mathrm{M} 3)$ gives the highest growth and yield of sweet corn compared to other treatments. Person.
\end{abstract}

Keywords: Organic Fertilizer, NPK Fertilizer, Sweet Corn.

\section{Introduction}

Sweet corn or often referred to as sweet corn (Zea mays saccataraStrut), is a type of corn known in Indonesia. This plant is widely consumed because it has a sweet taste compared to ordinary corn. And the production life is shorter[1].

Indonesia is a tropical country, generally corn is cultivated in areas with limited rainfall and irrigation, so the loss of water from land either through evaporation, surface water flow or weed evaporation must be minimized. Therefore, the provision of water in the field must be efficient by plants. Corn is a plant that is tolerant of little water, but if the irrigation is lacking in moisture it can reduce yield. If it happens low and hot weather causes photosynthesis to decrease and the results decrease[2].

The increase in sweet corn production in the past year has also been faced with various obstacles both technical and nontechnical. Farmers who generally lack farming capital are increasingly powerless because of the increasing prices of production facilities, especially the increase in fertilizer prices. Fertilizer is important in increasing production [3]. Besides being able to increase corn yields quantitatively it can also improve the quality of corn plants [4].

Sweet corn has great potential as a leading commodity of food crops in order to improve food security and diversification of nutritious food for the population. Consumer demand (market) for sweet corn tends to increase from year to year, so it is a profitable business opportunity, because this plant has high economic value. In connection with the high market demand, it is necessary to increase the productivity of sweet corn crops, where efforts to increase national sweet corn production and production are carried out through extensification, diversification and rehabilitation programs.

Sweet corn production in 2004 was pushed for an area of 1 ha which only produced 0.8 tons of peel. This is mainly caused by raw materials and has not been supported by the application of good cultivation. Whereas according to BPS Data (2007) shows that corn plants in Indonesia have a production of $34.50 \mathrm{kw} / \mathrm{ha}$ and in Papua area of $14.21 \mathrm{kw} / \mathrm{ha}[4]$.

Plant and environmental management in crop cultivation Sweet corn also affects production and productivity, for example in terms of farming techniques, fertilization, pest control that is not in accordance with the advanced technology package that develops in the field or the results of research by agricultural experts[5].

In order to meet market needs, it is necessary to improve the method of farming, including the use of fertilizers, one of the fertilizers used is to use organic fertilizer (manure) and organic where $b$

oth fertilizers have a function as a nutrient source for plants[6].

Manure is a significant by-product, consisting of solid and liquid dirt from farm animals mixed with food waste, can add nutrients in the soil[7]. The provision of manure, in addition to increasing the availability of nutrients, can also improve the physical properties of the soil. Some physical properties of soil that can be affected by manure include aggregate stability, volume weight, total pore space, plasticity and holding capacity manages[8].

Manureto provide organic food, improve soil structure, and increase water holding capacity[9]. Whereas organic fertilizer TSP type of fertilizer containing nutrients, and nutrients is needed in the growth and development of plants, especially corn plants [1]. 
Based on the description above, it is necessary to conduct research on the Test of Giving Organic Fertilizer and NPK Fertilizer to the Growth and Yield of Sweet Corn (zea mays.l).

\section{Research Methods}

On This research was carried out in the Experimental Garden of the Faculty of Agriculture Merdeka University in Surabaya in Karah Village, Jambangan Subdistrict, Surabaya City with an altitude of \pm 5 (five) meters above sea level. This study used a randomized block design (RBD) arranged factorial consisting of two factors: the provision of organic fertilizer (cage) with 3 levels of treatment $(\mathrm{K})$ and the provision of NPK fertilizer with 3 levels of treatment $(\mathrm{M})$. Each treatment was repeated 3 times and each treatment combination consisted of two sample plants.

Observations made on plant length $(\mathrm{cm})$ plant length measurements were carried out from the ground to the longest leaf by means of the leaf being clasped up and measured using a ruler / meter carried out at the age of 14 days after planting with a 2week interval, namely; 14, 28, 42 and 56 HST. The number of leaves counting leaves that have opened perfectly is done starting at the age of 14 days after planting at 2-week intervals namely; 14 , 28, 42, and 56 HST.

Stem Diameter $(\mathrm{cm})$. Measuring the diameter of the stem is done by measuring the stem diameter of about $10 \mathrm{~cm}$ from the surface of the ground using a calipse. It is done when the plants are 2 weeks after planting at 14 days intervals namely; 14, 28, 42 and 56 HST.

The length of the Cob $(\mathrm{cm})$ measurements is done by measuring the cob from the base to the tip of the cob at the end of the observation. Cob diameter $(\mathrm{cm})$ measurements are carried out by using a caliper run in the center of the center of the cob. Fresh weight of cob without klobot, weighing of cobs is done after the whole klobot has been peeled at the end of observation. Collection of yields or harvesting of sweet corn crops in the form of corn cobs, harvesting is done after sweet corn is ripe enough, ie at the age of 60 days after planting.

\section{Results and Discussion}

\subsection{Plant length}

Results of variance analysis showed that the interaction between the treatment of organic fertilizer and NPK fertilizer on plan length at all ages of observation did not show a significant difference. Separately the treatment of giving manure and NPK fertilizer to the length of the plant at all ages of observation showed a very real difference.

The average length of plants in the treatment of organic fertilizer and NPK fertilizer can be seen in Table 1 .

Table 1: Average Plant Length Due to Treatment of Organic Fertilizers and NPK Fertilizers at Various Observation Age

\begin{tabular}{|c|c|c|c|c|}
\hline \multirow{2}{*}{ Treatment } & \multicolumn{4}{|c|}{ Plant Length $(\mathrm{cm})$} \\
\cline { 2 - 5 } & 14 HST & 28 HST & $42 \mathrm{HST}$ & $56 \mathrm{HST}$ \\
\hline K 1 & $39.31 \mathrm{a}$ & $72.00 \mathrm{a}$ & $111.00 \mathrm{a}$ & $154.89 \mathrm{a}$ \\
\hline K 2 & $42.06 \mathrm{~b}$ & $84.33 \mathrm{~b}$ & $126.94 \mathrm{~b}$ & $165.28 \mathrm{~b}$ \\
\hline K 3 & $45.96 \mathrm{c}$ & $90.94 \mathrm{c}$ & $134.44 \mathrm{c}$ & $187.56 \mathrm{c}$ \\
\hline BNT 5\% & 1.89 & 5.54 & 7.10 & 9,93 \\
\hline M 1 & $40.20 \mathrm{a}$ & $75.75 \mathrm{a}$ & $117.00 \mathrm{a}$ & $173.00 \mathrm{a}$ \\
\hline M 2 & $42.68 \mathrm{~b}$ & $\mathrm{bc}$ & $83.17123 .94 \mathrm{a}$ & $185.78 \mathrm{bc}$ \\
\hline M 3 & $44.44 \mathrm{c}$ & $88.56 \mathrm{c}$ & $131,44 \mathrm{~b}$ & $194.89 \mathrm{c}$ \\
\hline BNT 5\% & 1.89 & 5.54 & 7.10 & 9.93 \\
\hline
\end{tabular}

Description: The numbers accompanied by different letters in the same column show significantly different in the BNT test 5\% HST: Weeks after Planting.

In the Table 1 seen that the treatment of organic fertilizer, the longest plant length was achieved in Ktreatment3, which was $45.96 \mathrm{~cm}$ at the age of $14 \mathrm{HST} ; 90.94 \mathrm{~cm}$ at the age of $28 \mathrm{HST}$;
$134.44 \mathrm{~cm}$ at the age of $42 \mathrm{HST}$ and $187.56 \mathrm{~cm}$ when the plant was 56 HST. The lowest yield was obtained in Ktreatment1, while the longest length of plant in NPK fertilizer treatment was achieved in Mtreatment3, which was $44.44 \mathrm{~cm}$ when the plant was $14 \mathrm{HST}$; $88.56 \mathrm{~cm}$ when the plant is $28 \mathrm{HST} ; 131.44 \mathrm{~cm}$ at the time the plant was $42 \mathrm{HST}$ and $194.89 \mathrm{~cm}$ when the plant was 56 HST. The lowest results were obtained at treatment M1 at all ages of observation.

This is because organic fertilizer has a role in the availability of nutrients, where nutrients are needed by plants for plant growth and development, including the growth of leaves and stems. In accordance with Syarief[2], the number and size of leaves are influenced by genotypes and the environment (including nutrients or organic matter). And it is also said that plants in their growth require organic and organic nutrients. Organic fertilizer is very important for plant life because it can improve soil structure, increase water absorption and increase living conditions in the soil Providing organic matter has a residual effect in increasing the infiltration of water into the soil and increasing nutrient availability that can increase crop production. According to Rismunandar[10], organic matter is a soil component that determines the potential of soil fertility. Organic matter active in the soil affects physical properties, soil chemistry.

\subsection{Number of Leaves}

The results of variance analysis showed that the interaction between the treatment of organic fertilizer and NPK fertilizer on the number of leaves at all ages of observation did not show a significant difference. Separately the treatment of giving organic fertilizer and NPK fertilizer to the length of plants at all ages of observation showed a very real difference. The average number of leaves in the treatment of organic fertilizer and NPK fertilizer can be seen in Table 2 .

Table 2: Font Specifications for A4 Papers

\begin{tabular}{|l|l|c|c|c|}
\hline \multirow{2}{*}{ Treatment of } & \multicolumn{5}{|c|}{ Number of Leaves (Strands) } \\
\cline { 2 - 5 } & 14 HST & 28 HST & 42 HST & 56 HST \\
\hline K 1 & $3.72 \mathrm{a}$ & $72.00 \mathrm{a}$ & $111.00 \mathrm{a}$ & $154.89 \mathrm{a}$ \\
\hline K 2 & $3.94 \mathrm{a}$ & $84.33 \mathrm{~b}$ & $126.94 \mathrm{~b}$ & $165.28 \mathrm{~b}$ \\
\hline K 3 & $4.28 \mathrm{~b}$ & $90.94 \mathrm{c}$ & $134.44 \mathrm{c}$ & $187.56 \mathrm{c}$ \\
\hline BNT 5\% & 0.31 & 5.54 & 7.10 & 9,93 \\
\hline M 1 & $3.61 \mathrm{a}$ & $75.75 \mathrm{a}$ & $117.00 \mathrm{a}$ & $173.00 \mathrm{a}$ \\
\hline M 2 & $3.89 \mathrm{a}$ & $\mathrm{bc}$ & $83.17123 .94 \mathrm{a}$ & $185.78 \mathrm{bc}$ \\
\hline M 3 & $4.44 \mathrm{~b}$ & $88.56 \mathrm{c}$ & $131,44 \mathrm{~b}$ & $194.89 \mathrm{c}$ \\
\hline BNT 5\% & 0.31 & 5.54 & 7.10 & 9.93 \\
\hline
\end{tabular}

Description: The numbers accompanied by different letters in the same column show significantly different in the BNT test 5\% HST: Weeks after Planting.

Table 2 seen that in the treatment of organic fertilizer, the highest number of leaves was achieved in Ktreatment3, which was 4.28 strands at the age of $14 \mathrm{HST} ; 8.73$ strands at age $28 \mathrm{HST} ; 12.06$ strands at the age of $42 \mathrm{HST}$ and 15.11 strands when the plant was 56 HST. The lowest yield was obtained in Ktreatment1, while the highest number of leaves in NPK fertilizer treatment was achieved in treatment M3, which was 4.44 strands when the plant was 14 HST; 8.28 strands when the plant is 28 HST; 12.11 strands at the time the plants were 42 HST and 15.00 strands when the plant was 56 HST. The lowest results were obtained at treatment M1 at all ages of observation.

This is because both organic fertilizer or NPK fertilizer as organic fertilizer have an important role to influence plant growth, both vegetative growth and generative growth. In accordance with Haryadi's opinion [11], that the role of fertilizer greatly affects plant growth in general. Plant growth is related to three important processes, namely cell division, cell extension and the first stage of cell differentiation. These three processes require a number of carbohydrates for their development, because the carbohydrates that are formed will be compounded with nitrogen compounds to form protoplasm formed at growing points. The more inventory of 
carbohydrates available, the faster the rate of the three processes, so that plant growth will be faster, and vice versa. The availability of carbohydrates formed in plants is affected by the availability of nutrients for these plants.

\subsection{Stem Diameter}

Variation analysis results showed that the interaction between organic fertilizer treatment and NPK fertilizer on stem diameter at all ages of observation did not show a significant difference. Separately the treatment of giving organic fertilizer and NPK fertilizer to the stem diameter did not show a significant difference at the age of 14 days after planting, at the age of observation 28 days after planting, 42 days after planting and 56 days after planting showed a very real difference. The average stem diameter in the treatment of organic fertilizer and NPK fertilizer can be seen in Table 3 .

Table 3: Average Stem Diameter $(\mathrm{cm})$ Due to Treatment of Organic Fertilizers and NPK Fertilizers in Various Age of Observation

\begin{tabular}{|l|l|c|c|c|}
\hline \multirow{2}{*}{ Treatment of } & \multicolumn{5}{|l|}{ Stem Diameter $(\mathrm{cm})$} \\
\cline { 2 - 5 } & 14 HST & $28 \mathrm{HST}$ & $42 \mathrm{HST}$ & $56 \mathrm{HST}$ \\
\hline K 1 & 1.12 & $72.00 \mathrm{a}$ & $111.00 \mathrm{a}$ & $154.89 \mathrm{a}$ \\
\hline K 2 & 1.13 & $84.33 \mathrm{~b}$ & $126.94 \mathrm{~b}$ & $165.28 \mathrm{~b}$ \\
\hline K 3 & 1.18 & $90.94 \mathrm{c}$ & $134.44 \mathrm{c}$ & $187.56 \mathrm{c}$ \\
\hline BNT 5\% & tn & 5.54 & 7.10 & 9,93 \\
\hline M 1 & 1.09 & $75.75 \mathrm{a}$ & $117.00 \mathrm{a}$ & $173.00 \mathrm{a}$ \\
\hline M 2 & 1.14 & $\mathrm{bc}$ & $83.17123 .94 \mathrm{a}$ & $185.78 \mathrm{bc}$ \\
\hline M 3 & 1.2 & $88.56 \mathrm{c}$ & $131,44 \mathrm{~b}$ & $194.89 \mathrm{c}$ \\
\hline BNT 5\% & tn & 5.54 & 7.10 & 9.93 \\
\hline
\end{tabular}

Description: The numbers accompanied by different letters in the same column show significantly different in the BNT test $5 \%$. HST : Sunday after Planting. tn : Not Different Real.

Table 3 shows that in the treatment of organic fertilizer, the largest stem diameter was achieved in Ktreatment3, which was $1.18 \mathrm{~cm}$ at the age of $14 \mathrm{HST} ; 1.81 \mathrm{~cm}$ at the age of $28 \mathrm{HST} ; 2.21 \mathrm{~cm}$ at the age of $42 \mathrm{HST}$ and $2.55 \mathrm{~cm}$ when the plant is 56 HST. The lowest yield was obtained in Ktreatment1, while the largest stem diameter in NPK fertilizer treatment was achieved in treatment M3, which was $1.2 \mathrm{~cm}$ when the plant was $14 \mathrm{HST} ; 1.78 \mathrm{~cm}$ when the plant is $28 \mathrm{HST} ; 2.21 \mathrm{~cm}$ at the time the plant was $42 \mathrm{HST}$ and $2.59 \mathrm{~cm}$ when the plant was 56 HST. The lowest results were obtained at treatment M1 at all ages of observation.

This is due to the vegetative growth phase requiring high nutrient elements in which the much needed nutrients are $\mathrm{N}$ elements and it is found in NPK fertilizer. Nitrogen has an important role, especially to stimulate overall plant growth, especially stem diameter, and in its growth also requires good media so that its growth can be maximized, namely the availability of manure.

Organic fertilizer is one of the fertilizers that can improve and maintain the physical, chemical and biological fertility of the soil and by using organic fertilizers can increase the yield of origin treated by other factors such as inorganic fertilization, good soil treatment, use of superior seeds, adequate irrigation and eradication of pest the incentive[12].

\subsection{Cob Length, Cob Diameter and Cob Weight with- out Clobot}

The results of variance analysis showed that the interaction between the treatment of organic fertilizer and NPK fertilizer on ear length, ear diameter and ear weight without klobot did not show a significant difference. Separately the treatment of giving organic fertilizer to ear length and ear diameter did not show a real difference, but the weight of the cob without a cow showed a very real difference. The treatment of NPK fertilizer on ear length, ear diameter and ear weight without klobot shows a very real difference. The average ear length, ear diameter and ear weight without klobot on the treatment composition of manure and NPK fertilizer can be seen in Table 4
Table 4 shows that the treatment of organic fertilizer, ear length, ear diameter and ear weight without the biggest clobot was achieved in the treatment. K3, respectively $25.67 \mathrm{~cm}, 4.56 \mathrm{~cm}$ and 261.39 grams, while the lowest yield was obtained in treatment K1. Whereas the ear length, ear diameter and ear weight without the biggest klobot on NPK fertilizer treatment were achieved at Mtreatment3, respectively $27.39 \mathrm{~cm}, 4.78 \mathrm{~cm}$ and 266.72 grams. The lowest results were obtained at treatment M1 at all ages of observation.

This is thought to be due to its own elemental properties, where Nitrogen has a major role to stimulate overall plant growth, especially the stems, branches and leaves. In addition Nitrogen has an important role in the formation of leaf green matter which plays an important role in the process of photosynthesis, forming proteins, fat, and various other organic compounds. Phosphorus has a role in stimulating root growth, especially the roots of seeds and young plants. It also acts as the formation of a number of certain proteins, helps assimilation, breathing while accelerating flowering, cooking seeds and fruit. In accordance with the opinion of Harjadi, S., [11], that the role of fertilizer greatly affects plant growth in general.

Table 4: Average Cob Length $(\mathrm{cm})$, Cob Diameter $(\mathrm{cm})$ and Cob Weight without Clobot (grams) Due to Treatment of Organic Fertilizer and NPK Fertilizer at Various Observation Age.

\begin{tabular}{|l|l|c|c|c|}
\hline \multirow{2}{*}{$\begin{array}{l}\text { Treatment } \\
\text { of } \\
\text { K 1 }\end{array}$} & \multicolumn{1}{|l|}{ Cob Length $(\mathrm{cm})}$, & \multicolumn{4}{l|}{} \\
\cline { 2 - 5 } & $21.78 \mathrm{a}$ & $\begin{array}{c}28 \\
\text { HST }\end{array}$ & $42 \mathrm{HST}$ & $56 \mathrm{HST}$ \\
\hline K 2 & $24.33 \mathrm{ab}$ & $72.00 \mathrm{a}$ & $111.00 \mathrm{a}$ & $154.89 \mathrm{a}$ \\
\hline K 3 & $25.67 \mathrm{~b}$ & $84.33 \mathrm{~b}$ & $126.94 \mathrm{~b}$ & $165.28 \mathrm{~b}$ \\
\hline $5 \%$ BNT & 2.93 & $90.94 \mathrm{c}$ & $134.44 \mathrm{c}$ & $187.56 \mathrm{c}$ \\
\hline M 1 & $20.89 \mathrm{a}$ & 5.54 & 7.10 & 9,93 \\
\hline M 2 & $23.50 \mathrm{a}$ & $75.75 \mathrm{a}$ & $117.00 \mathrm{a}$ & $173.00 \mathrm{a}$ \\
\hline M 3 & $27.39 \mathrm{~b}$ & $\mathrm{bc}$ & $\begin{array}{c}83.17123 .94 \\
\mathrm{a}\end{array}$ & $\begin{array}{c}185.78 \\
\mathrm{bc}\end{array}$ \\
\hline BNT 5\% & 2.93 & $88.56 \mathrm{c}$ & $131,44 \mathrm{~b}$ & $194.89 \mathrm{c}$ \\
\hline $\begin{array}{l}\text { Treatment } \\
\text { of }\end{array}$ & $\begin{array}{l}\text { Cob Length } \\
\mathrm{cm}),\end{array}$ & 5.54 & 7.10 & 9.93 \\
\hline
\end{tabular}

Description: The numbers accompanied by different letters in the same column show significantly different in the BNT test $5 \%$. HST: Sunday after Planting Plant.

Growth is related to three important processes, namely cleavage cell, cell extension and the first stage of cell differentiation. These three processes require a number of carbohydrates for their development, because the carbohydrates that are formed will be compounded with nitrogen compounds to form protoplasm formed at growing points. The more inventory of carbohydrates available, the faster the rate of the three processes, so that plant growth will be faster, and vice versa. The availability of carbohydrates formed in plants is affected by the availability of nutrients for these plants. Phosphate-fertilized plants can develop more roots than nonfertilized plants, where the availability of phosphate first increases photosynthesis, which in turn increases root growth. This is because the root is an organ in charge of aborting nutrients from the planting medium to meet the needs of plant growth. The results of the synthesis photo are translocated throughout the plant organs[13].

\section{Conclusion}

Overall the treatment of the combination of organic fertilizer and NPK fertilizer on the growth and yield of sweet corn plants did not show a real effect. Separately the treatment of organic fertilizer gave a very real effect on all observation variables, the average organic fertilizer as much as 17.5 tons / ha or $1.5 \mathrm{~kg} / \tan (\mathrm{K} 3)$ gave the highest growth and yield of sweet corn compared to the other treatment and separately the treatment of NPK fertilizer gave a very real influence on all observation variables, the average NPK fertilizer with a composition of $450 \mathrm{~kg}$ Urea + $150 \mathrm{~kg}$ TSP + $75 \mathrm{~kg} \mathrm{KCl}) / \mathrm{Ha}$ or $9 \mathrm{gr}+3 \mathrm{gr}+15 \mathrm{gr} / \tan (\mathrm{M} 3)$ gave the highest 
growth and yield of sweet corn plants compared to other treatments.

\section{Acknowledgement}

We would like to express our gratitude to our institution of Merdeka University Surabaya for their assistance and support to improve the research. We also want to show our gratitude to (Sri Hidayati, Mahrus Ali, Sri Purwanti, Nurul Huda, Nurlina) to share their scholarship and wisdom to us during this research. We are also very grateful for the comments of fellow lecturers outside the Merdeka University Surabaya.

\section{References}

[1] R. Palungkun and B. Asiani, "Sweet Corn-Baby Corn: Peluang Bisnis, Pembudidayaan dan Penanganan Pasca Panen," Penebar Swadaya. Jakarta, vol. 79, 2004.

[2] N. Ayunda, "Pertumbuhan dan Hasil Tanaman Jagung Manis (Zea Mays Saccharata Sturt.) Pada Beberapa Konsentrasi Sea Minerals,' Fac. Agric. Univ. Taman Siswa, Padang, 2014

[3] A. Mahrus, H. Bambang Wicaksono, Nurlina, H. Cholil, and M. Sri Wiwoho, "Mapping of Biomass Production of Land Damage Assessment to Reduce Environmental Changes In East Java Probolinggo," in MATEC Web of Conferences, 2017, vol. 138, p. 09004

[4] A. Maruapey, "Pengaruh Jarak Tanam Dan Jenis Pupuk Kandang Terhadap Pertumbuhan Gulma Dan Hasil Jagung Manis," in Fakultas Pertanian Unamin Sorong. Prosiding Seminar Nasional Serealia Maros. Balai Penelitian dan Pengembangan Pertanian. Maros, 2011.

[5] I. H. R. Rukmana, Budi Daya RUMPUT UNGGUL, Hijauan Makanan Ternak. Kanisius, 2005.

[6] R. Rahim et al., "Pest Plant Disease Prevention and Identification System Using Certainty Factor Method," Int. J. Eng. Technol., vol. 7, no. 3.2, pp. 763-765, Jun. 2018

[7] W. Pancapalaga, "Pengaruh rasio penggunaan limbah ternak dan hijauan terhadap kualitas pupuk cair,”J. Gamma, vol. 7, no. 1, 2013.

[8] G. Soepardi, Sifat dan ciri tanah. 1983

[9] P. C. GROWMORE and R. MELZA, "PERTUMBUHAN DAN HASIL JAGUNG BABY CORN VARIETAS PIONEER-12 PADA TANAH ULTISOL DENGAN PEMBERIAN PUPUK ORGANIK DAN PUPUK.'

[10] H. Sunaryono, "Rismunandar. 1990," Kunci Bercocok Tanam Sayur-Sayuran Penting di Indones. (Produksi Hortik. II).

[11] M. M. S. S. Harjadi, Pengantar agronomi. PT. Gramedia, Jakarta, 1979.

[12] W. Hartatik and L. R. Widowati, "Pupuk kandang," Dalam, vol. 7. Pupuk Organik dan Pupuk Hayati. Balai Besar Litbang Sumberdaya Lahan Pertanian, Bogor. Penambahan, 2006.

[13] V. Simanullang, M. K. Bangun, and H. Setiado, "Respon Pertumbuhan Beberapa Varietas Timun (Cucumi S Sat I Vus L.) Terhadap Pemberian Pupuk Organik," J. Agroekoteknologi Univ. Sumatera Utara, vol. 2, no. 2, 2012. 